\title{
Impact of COVID-19 on Acute Viral Bronchiolitis Hospitalization Among Infants in North India: Correspondence
}

\author{
Pathum Sookaromdee ${ }^{1} \cdot$ Viroj Wiwanitkit $^{2}$
}

Received: 11 October 2021 / Accepted: 12 November 2021/Published online: 14 January 2022

(c) Dr. K C Chaudhuri Foundation 2021

To the Editor: We like to share ideas on the publication "Impact of COVID-19 on Acute Viral Bronchiolitis Hospitalization Among Infants in North India" [1]. Takia et al. concluded that "The infection prevention and control measures (use of face mask, hand hygiene, social distancing, ... during the pandemic are the possible reasons for the reduction in the incidence, hospitalization, and severity of pediatric infectious respiratory diseases including AVB" [1]. We agree with Takia et al. that there are several possible reasons for observed situation on acute viral bronchitis (AVB). The observation in this report is similar to that reported from South America [2].

Basically, the epidemiology of AVB might change due to season [3]. In each year, the pattern of the season fluctuation might occur. Comparison of the current data to the data of previous years might be useful. Finally, there is a new report on post-COVID-19 airway complication [4]. The continuous monitoring of epidemiological pattern after COVID-19 outbreak is interesting.

\section{Declarations}

Conflict of Interest None.

\section{References}

1. Takia L, Awasthi P, Angurana SK. Impact of COVID-19 on acute viral bronchiolitis hospitalization among infants in North India. Indian J Pediatr. 2021;88:1154.

2. Friedrich F, Ongaratto R, Scotta MC, et al. Early impact of social distancing in response to coronavirus disease 2019 on hospitalizations for acute bronchiolitis in infants in Brazil. Clin Infect Dis. 2021;72:2071-5.

3. Nicolai T, Pohl A. Acute viral bronchiolitis in infancy: epidemiology and management. Lung. 1990;168:396-405.

4. Grimaud E, Challiol M, Guilbaud C, et al. Delayed acute bronchiolitis in infants hospitalized for COVID-19. Pediatr Pulmonol. 2020;55:2211-2.

Publisher's Note Springer Nature remains neutral with regard to jurisdictional claims in published maps and institutional affiliations.

Pathum Sookaromdee

apthumsook@gmail.com

1 Private Academic Consultant, 112, Bangkok 10226, Thailand

2 Department of Community Medicine, Dr DY Patil University, Pune, Maharashtra, India 